\title{
Using thermal units for crop coefficient estimation and irrigation scheduling improves yield and water productivity of corn (Zea mays L.) \\ by
}

\author{
Bautista-Capetillo C. ${ }^{1}$ M. ASCE, Zavala M. ${ }^{2}$, Martínez-Cob A. ${ }^{3}$
}

\section{$\underline{\text { Abstract }}$}

Estimates of daily crop coefficient $(\mathrm{Kc})$ for corn and irrigation scheduling were performed during 2009 and 2010 by means of two approaches: treatment I, computation of Kc using the FAO method; treatment II, computation of Kc from relative fraction of thermal units. Corn crop water requirements and irrigation gross depth for treatment I were about 25 to $33 \%$ lower than that for treatment II in 2009 and 2010 respectively. However, the performance of the treatment II was better in terms of grain yield which was $9.2 \mathrm{Mg} \mathrm{ha}^{-1}$ (in 2009) and $9.4 \mathrm{Mg} \mathrm{ha}^{-1}$ (in 2010), about 37 and $29 \%$ higher than that for treatment I. Water productivity was about $10 \%$ higher for treatment II during 2009 and practically the same than that of treatment I for 2010. Due to the year-to-year variability the water productivity was about 25 \% (treatment II) and 11 \% (treatment I) for 2010 than for 2009. Finally, economic productivity for treatment II was $2162 \$$ ha $^{-1}$ for both seasons, much higher than that for treatment I, 1575 (in 2009) and 1679 (in 2010) \$ ha-1. These results confirm that the use of fraction of thermal units to estimate corn crop coefficient has improved the yield, and the water management of this crop under the conditions of this study. Because of the limitations of the study (only two years and one experimental plot), further evaluations under other conditions (climatic, cultivar, etc.) should be performed.

Keywords: Daily corn crop coefficients, water use productivity, grain yield, economic productivity.

${ }^{1}$ Professor, Planeación de Recursos Hidráulicos, Universidad Autónoma de Zacatecas, Av. Ramón López Velarde 801, 98000 Zacatecas, Mexico.

${ }^{2}$ Professor, Planeación de Recursos Hidráulicos, Universidad Autónoma de Zacatecas, Av. Ramón López Velarde 801, 98000 Zacatecas, Mexico.

3 Tenured Scientist, Departamento Suelo y Agua, Estación Experimental de Aula Dei, CSIC. P. O. Box 13034. 50080 Zaragoza, Spain.

* Corresponding author: baucap@uaz.edu.mx 


\section{Introduction}

2 Total irrigated area in Mexico is 6.46 Mha. Corn crop covers $22 \%$ of this surface, with an

3 average yield around 7.33 $\mathrm{Mg} \mathrm{ha}^{-1}$; nevertheless, yields in Northern and Central Mexico

4 (semi-arid climate) decrease until $5.37 \mathrm{Mg} \mathrm{ha}^{-1}$.. Factors such as crop genetics, soil

5 characteristics, fertilizer application, and water requirements affect corn production. Tyagi

6 et al. (2003) showed yields and quality of maize declining due to inadequate water supply

7 and inappropriate irrigation scheduling. Kiziloglu et al. (2009) indicated that water stress

8 has an important effect on water consumption and yield of maize and reported a positive,

9 strong linear relationship between yield and water use. Improvement of irrigation water

10 management calls for an accurate knowledge of crop water requirements or crop

11 evapotranspiration (ETc).

12 ETc is generally calculated as the product of a crop coefficient $\left(\mathrm{K}_{\mathrm{c}}\right)$ and the reference

13 evapotranspiration $\left(\mathrm{ET}_{\mathrm{o}}\right.$ ) (Allen et al. 1998). Kc varies along the crop phenological

14 development, i.e. Kc can be plotted as a function of time during the crop season. Different

15 methodologies have been proposed to plot Kc curves. The Food and Agriculture

16 Organization of the United Nations (FAO) proposed defining four phenological stages

17 (initial, development, mid-season and late or final stages), estimating three Kc values (at

18 the initial, $\mathrm{K}_{\mathrm{ini}}$, mid-season, $\mathrm{Kc}_{\mathrm{mid}}$, and late-season, $\mathrm{Kc}_{\mathrm{end}}$ ), and connecting straight line

19 segments through each of the four growth stages (Allen et al. 1998); horizontal lines are

20 drawn through $\mathrm{Kc}_{\mathrm{c}}$ in the initial and mid-season stages, while diagonal lines are drawn

21 from $K c_{\text {ini }}$ to $K c_{\text {mid }}$ within the course of the development stage and from $\mathrm{Kc}_{\text {mid }}$ to $\mathrm{Kc}_{\text {end }}$

22 within the course of the late-season stage. 
1 Applying the approach proposed by Allen et al. (1998) is quite simple. However, the

2 practical definition of the four crop growth stages is quite cumbersome for a great number

3 of crops because these stages are not based on standard phenological stages as used by

4 farmers or technicians. In addition, the approach proposed by Allen et al. (1998) requires

5 the crop growth stages and the general average meteorological conditions be defined in

6 advance at the beginning of the season. Thus, in practice, this leads to the use of a fixed Kc

7 curve along different years particularly for real time scheduling irrigation. Alternative

8 approaches estimate $\mathrm{Kc}_{\mathrm{c}}$ as a continuous function of other parameters easier to determine

9 along the season allowing the Kc curve be modified as a function of the year-to-year 10 variability. Thus, Kc can be computed as a function of days after sowing (Ojeda-

11 Bustamante et al. 2004; Kang et al. 2003; Sepaskhah and Andam 2001) although this

12 approach show limitations for real-time crop water requirements estimation because they

13 do not take into account the environmental variations that occur year by year and the

14 effect of cultural factors on the rate of canopy development (Martínez-Cob 2008). Other

15 authors have proposed obtaining the $\mathrm{K}_{\mathrm{c}}$ curve as a function of several other parameters:

16 leaf area index, percent ground cover and cumulative growing degree days (or thermal

17 units, TU). These approaches use variables that are more closely related to crop

18 development and they respond to the year-to-year variability. Temperature variability

19 prevails as one of the most important environmental factors affecting the growth and yield

20 of crops (Yan and Hunt 1999). That variability has a direct and strong influence on crop

21 development (Ritchie and NeSmith 1991). Several previous studies have developed

22 equations to estimate crop coefficients as a function of that variable, either using the

23 absolute values of cumulative thermal units (TU) or using the fraction of thermal units

24 (FTU, i.e the fraction of cumulative TU at a given period to the total seasonal cumulative 
1 TU) (Martínez-Cob 2008; Kang et al. 2003; Grattan et al. 1998; Steele et al. 1996; Nielsen and

2 Hinkle 1996; Amos et al. 1989; Sammis et al. 1985). The use of thermal units is

3 recommended as it can be easily computed from readily available daily air temperature at

4 on-line weather station networks. The use of FTU is preferred over the use of TU as it

5 allows a general application of the crop coefficient curve across cultivars requiring

6 different TU totals from emergence or budbreak to harvest or physiological maturity

7 (Amos et al. 1989). The generalization of these types of equations would require their

8 validation for conditions different from which they were developed. This validation

9 studies should focus on the consequences on crop water management and crop

10 productivity of using those equations for irrigation scheduling as compared to using the

11 standard, worldwide applied procedure proposed by Allen et al. (1998).

12 A number of researches have evaluated yields for various crops under different 13 experimental irrigation doses expressed as percentages of ETc computed using Kc 14 derivedfrom the FAO or other alternative approaches (Bezerra et al. 2012; Dehghanisanij et 15 al. 2009; Dioudis et al. 2009; Ko and Piccinni 2009; López-Urrea et al. 2009; Vories et al. 16 2009; Kar et al. 2007; Ojeda-Bustamente et al. 2006). Nevertheless, there is a lack of studies 17 comparing several $\mathrm{Kc}$ approaches in terms of seasonal crop water requirements, yields 18 and water productivity.

19 The objectives of this work were: 1) to estimate daily corn $K_{c}$ values from FAO 20 methodology as well as using the equation developed by Martínez-Cob (2008) to estimate 21 the corn $\mathrm{K}_{\mathrm{c}}$ curve from the fraction of thermal units equation (FTUMC); 2) to compare the 22 corn crop water requirements and irrigation doses estimated using both approaches; 3) to 
1 evaluate the consequences of both irrigation approaches on the water use productivity and

2 the corn crop production.

3

4

5

6

7

8

9

10

11

12

13

14

15

16

17 


\section{$1 \quad$ Material and methods}

2 The experimental work was conducted during the 2009 and 2010 growing seasons at a 5 ha

3 commercial farm located at Chupaderos aquifer, $18 \mathrm{~km}$ northeast from city of Zacatecas,

4 Mexico $\left(22^{\circ} 47^{\prime} 46.7^{\prime \prime} \mathrm{N}\right.$ latitude, $102^{\circ} 25^{\prime} 21.8^{\prime \prime} \mathrm{W}$ longitude, altitude $\left.2077 \mathrm{~m}\right)$. The soil at

5 the experimental area is sandy clay loam (texture with $64.04 \%$ sand, $21.96 \%$ clay, and 14

$6 \%$ silt) with $3.2 \%$ organic matter content, field capacity of $0.36 \mathrm{~m}^{3} \mathrm{~m}^{-3} \%$ and permanent

7 wilting point of $0.18 \mathrm{~m}^{3} \mathrm{~m}^{-3}$. The climate is semiarid with minimum and maximum mean

8 monthly temperatures of $6.7^{\circ} \mathrm{C}$ (December and January) and $27.3^{\circ} \mathrm{C}$ (May), respectively.

9 Average annual precipitation is about $525 \mathrm{~mm}$ of which $80 \%$ occurs from June through

10 September.

11 Two treatments were established: a) treatment I: irrigation scheduling using the crop

12 coefficients estimated applying the FAO methodology adapted to the local conditions; b)

13 treatment II: irrigation scheduling using the crop coefficients estimated from the equation

14 developed by Martínez-Cob (2008). An experimental plot of 1 ha (50 m x $200 \mathrm{~m})$ was

15 established within the abovementioned commercial plot. This plot was divided in two

16 subplots (50 m x $100 \mathrm{~m}$ ), one for each treatment. Each subplot had three replications, 16.5

$17 \mathrm{~m} \times 100 \mathrm{~m}$ (about 22 rows within each replicate). At the end of the season, an area of $7.5 \mathrm{~m}$

$18 \times 7.0 \mathrm{~m}$, at the middle 10 rows of each replication, was sampled for yield determination.

19 The experimental plot was sown with corn (H-311 hybrid) on April 13 (2009) and April 3

20 (2010); harvesting dates were September 9 (2009) and August 30 (2010). Distance between

21 rows was $0.75 \mathrm{~m}$ and average seedling density was about 75,000 plants ha-1 ${ }^{-}$The hybrid $\mathrm{H}-$

22311 was obtained by the National Research Institute for Forestry, Agriculture and

23 Livestock of Mexico (INIFAP) as a cultivar suited for irrigated land in Mexico. It has been 
1 proved for several years under different experimental and practical conditions showing

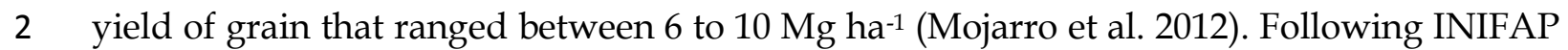

3 recommendations, a fertilizer dose of 200-80-00 (N-P-K) was applied for both years.

4 An automated weather station (Vantage Pro2 Davis Instruments) located $280 \mathrm{~m}$ south of

5 the experimental field was used to measure daily rainfall, daily average wind speed at $2 \mathrm{~m}$

6 above ground, daily average relative humidity, daily minimum and maximum air

7 temperature, and daily total solar radiation. These data were used to estimate $\mathrm{ET}_{\mathrm{o}}$ by the

8 FAO Penman-Monteith method (Allen et al. 1998).

9 For each replication and treatment, the water productivity was obtained by dividing the 10 corresponding grain yield by the volume of irrigation water applied (IGD), and the 11 economic productivity was estimated as the product of grain yield and market price of 12 corn; according to the Ministry of Agriculture, Livestock, Rural Development, Fisheries 13 and Food of the Mexican government the annual average price of corn for 2009 and 2010 14 was 235 \$ Mg-1, and 230 \$ Mg-1, respectively. An analysis of variance (ANOVA) (single 15 factor) was conducted using the MSExcel 2007 program, and the significance of the 16 differences between treatments for grain yield, water productivity and economic 17 productivity were tested.

\section{Corn crop coefficients}

19 From 2005 to 2008, Mojarro et al. (2008) performed a study to estimate crop coefficients 20 following the FAO methodology adapted to the local conditions of the Calera aquifer of 21 the State of Zacatecas (Mexico). This aquifer is placed $45 \mathrm{~km}$ from commercial farm used in 22 this experiment. The Kc curves and length of stages recommended by these authors for

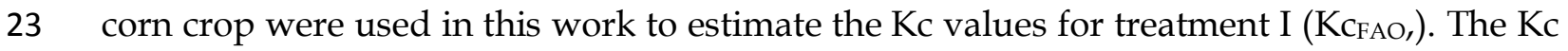


1 values for initial season, mid-season and late season were $K_{c_{\text {ini }}}=0.35, K_{c_{\text {mid }}}=1.22$, and

$2 \mathrm{~K}_{\mathrm{end}}=0.62$, with lengths of 45 days for initial stage, 30 days for development stage, 45 days

3 for mid-season stage, and 30 days for late stage. The same curve was used for both

4 seasons.

5 On the other hand, Martínez-Cob (2008) developed a corn crop coefficient curve as a

6 function of fraction of thermal units (FTU) under the semiarid climatic conditions of

7 Aragón (Spain). That equation was validated for the climatic conditions and cultivar used

8 in that study but it should be validated for different conditions and cultivars. Climate

9 conditions in Aragón (Spain) are different than those in Zacatecas (Mexico), with hotter

10 and drier summer when most of the corn development occurs. Thus treatment II used Kc

11 values estimated using the following equation developed by Martínez-Cob (2008):

$$
K c_{F T U_{-} i}=-3.4245 F T U_{i}^{3}+1.045 F T U_{i}^{2}+2.4973 F T U_{i}+0.2389
$$

12

13 where $K c_{F T U_{-} i}$ is the crop coefficient value for day $i$ and $F T U_{i}$ is the fraction thermal unit

14 for day $i$ calculated as:

15

$$
F T U_{i}=\frac{T U_{i}}{T T U}
$$

16 where $T T U$ is the total cumulative thermal units $\left({ }^{\circ} \mathrm{C}\right)$ and $T U_{i}$ is the cumulative thermal

17 units for day $i\left({ }^{\circ} \mathrm{C}\right)$; its values were computed as (Ritchie and NeSmith 1991):

$$
T U_{i}=T U_{i-1}+\left(T_{a}-T_{b}\right)_{i} \text { if } T_{a}>T_{b}
$$

18

$$
T U_{i}=T U_{i-1} \quad \text { if } T_{a} \leq T_{b}
$$


1 where $T U_{i-1}$ is the cumulative thermal units for day $i-1\left({ }^{\circ} \mathrm{C}\right), T_{a}$ is the average

2 temperature for day $i\left({ }^{\circ} \mathrm{C}\right)$ and $T_{b}$ is the basal temperature $\left({ }^{\circ} \mathrm{C}\right)$. Basal temperature was

3 assumed as $9^{\circ} \mathrm{C}$ (Ruiz-Corral et al. 2002) in this experiment.

4 Application of Eq. (1) requires a priori knowledge of the value of TTU adequate for the

5 cultivar and conditions under study. In this study, that value was not known at the onset

6 of the 2009 season. Thus TTU for 2009 corn season was considered as the average of $T T U$

7 computed for 2005-2008, between April 13 and September 9, the season length (150 days)

8 determined by Mojarro et al. (2008) as typical for corn in the area to apply the FAO

9 methodology. The average of these four values was $1661{ }^{\circ} \mathrm{C}$ (coefficient of variation, $3 \%$ ).

10 Temperature data for this period was taken from a weather station monitored by INIFAP

11 located around $15 \mathrm{~km}\left(22^{\circ} 45^{\prime} 26.1^{\prime \prime} \mathrm{N}\right.$ latitude, $102^{\circ} 30^{\prime} 36.0^{\prime \prime} \mathrm{W}$ longitude, altitude 2289

$12 \mathrm{~m})$ from the site of the experiment. Because an automatic weather station was available

13 next to the experimental plot during 2009, a TTU value was computed using the

14 temperature data registered at that station. Thus a value of $1768^{\circ} \mathrm{C}$ was obtained and used

15 for the 2010 season for treatment II. Considering that the abovementioned coefficient of 16 variation was $3 \%$, this TTU value of $1768{ }^{\circ} \mathrm{C}$ was within the confidence interval $(\mathrm{P}=0.05)$

17 of the average TTU value of $1661^{\circ} \mathrm{C}$.

19 Net corn crop water requirements and irrigation scheduling

20 During 2009, furrow irrigation was applied. A solid-set sprinkler irrigation system was

21 installed during that season and it became on operation for the 2010 season. Net corn crop

22 water requirements for both treatments were computed as follows:

$$
C W R_{s}=E T c_{s}-P E F_{s}
$$


1 where $C W R_{s}(\mathrm{~mm})$ is the water required by corn crop to compensate the loss of water as

2 evapotranspiration. $E T c_{s}(\mathrm{~mm})$ is the crop evapotranspiration (Eq. 5) and $P E F_{s}(\mathrm{~mm})$ is

3 the effective precipitation (Eq. 6). Due to the different irrigation systems, Eq. (4) during

42009 was applied for periods of varying length, ranging from 10 to 25 days, while during

52010 was applied on a weekly basis. $E T c_{s}$ and $P E F_{s}$ were estimated as follows:

$6 \quad E T c_{s}=\sum_{i=t}^{T_{s}} K c_{i} E T_{o_{-} i}$

7

8 where $E T_{o_{-} i}(\mathrm{~mm})$ is the reference evapotranspiration for day $i ; \mathrm{K}_{\mathrm{i}}$ is the crop coefficient

9 for day $i$ (either treatment I or treatment II); $t$ and $T_{s}$ are the first and last day of the 10 considered period.

$$
P E F_{s}=0.75 P_{s} \quad \text { if } P_{s}>0.2 E T_{o_{-} s}
$$

11

$$
P E F_{s}=0.00 \quad \text { if } P_{s} \leq 0.2 E T_{o_{-} s}
$$

12

13 where $P_{s}(\mathrm{~mm})$ and $E T_{o_{-} s}(\mathrm{~mm})$ are the precipitation and reference evapotranspiration,

14 respectively, for the considered period.

15

$$
I G D=\frac{C W R_{s}}{E_{a}}
$$

19 where $E_{a}$ is the application efficiency.

20 For the 2009 season, an application efficiency of $70 \%$ was assumed for the furrow

21 irrigation system used. This assumption was based on previously experimentation years

22 on the studied commercial field where soil physics and irrigation phases for a chili 
1 (Capsicum annuum L.) crop were characterized as well as $E_{a}$ was estimated using the

2 definition of Howell (2003) for application efficiency as the relation between irrigation

3 needed by the crop and water delivered to the field. Six inches gated pipe was used for the

4 application of irrigation water in furrows. The time consumed in each surface irrigation

5 event was calculated as:

$$
T_{r}=\frac{V_{a}}{Q_{g}}
$$

6

7 where $V_{a}$ is the volume applied in each irrigation event $\left(\mathrm{m}^{3}\right)$, calculated as the product of

8 irrigation gross depth (m), furrow length (in this study, $100 \mathrm{~m}$ ) and distance between

9 furrows (in this study, $0.75 \mathrm{~m}$ ). $Q_{g}$ is the water discharged by the gated pipe in each

10 furrow $\left(\mathrm{m}^{3} \mathrm{~h}^{-1}\right)$; and $T_{r}$ is the inflow time (h).

11 For the 2010 season, irrigation water was applied by a solid-set sprinkler irrigation system

12 with spacing between sprinklers of $12 \mathrm{~m}$ in rectangular arrangement; sprinklers model

13 WR-33 equipped with two nozzles $(3.97 \mathrm{~mm}$ and $3.18 \mathrm{~mm})$ manufactured by Waderain

14 Inc. (Portland, Oregon, USA) were used in the experiment. The system was operating at

$15200 \mathrm{kPa}$ of hydraulic pressure. For this pressure and the rectangular framework used,

16 three preliminary experimental tests were performed to determine the coefficient of

17 uniformity (CU) (Christiansen, 1942) of the water application under different wind

18 conditions $\left(0.6,1.2,2.1\right.$ and $\left.3.9 \mathrm{~m} \mathrm{~s}^{-1}\right)$ following the criteria outlined by Merriam and Keller

19 (1978). Average CU values of $93 \%, 91 \%, 83 \%$, and $76 \%$ were obtained for the wind

20 speeds tested $\left(0.6,1.2,2.1\right.$ and $3.9 \mathrm{~m} \mathrm{~s}^{-1}$, respectively). An application efficiency of $85 \%$ for

21 wind speeds lower than $2.0 \mathrm{~m} \mathrm{~s}^{-1}$ was claimed by the sprinkler nozzle producer. Recorded 
1 average wind speeds during the irrigation events rarely exceeded that threshold value.

2 The duration of each solid-set sprinkler irrigation event was estimated as:

3

$$
T_{s}=\frac{10 A I G D}{Q}
$$

4

5 where $T_{s}$ is the total operating hours of the sprinkler system (h), $A$ is the irrigated area

6 (0.5 ha for each experimental plot), 10 is a constant for units transformation, IGD is the

7 irrigation gross depth between two irrigation events $(\mathrm{mm})$, and $Q$ is the discharge by the

8 sprinkler $\left(\mathrm{m}^{3} \mathrm{~h}^{-1}\right)$. According to the Waderain Product Catalog, the discharge for WR-33

9 sprinkler is around $1.20 \mathrm{~m}^{3} \mathrm{~h}^{-1}$ for double nozzle operating at $200 \mathrm{kPa}$. Solid-set sprinkler

10 irrigation events were set for night time periods.

11

12

13

14

15

16

17

18

19

20

21 


\section{$1 \quad$ Results and discussion}

2 The meteorological conditions for the 2009 and 2010 corn seasons (13 April to 9 September

3 in 2009, and 3 April to 30 August in 2010) are presented in Figure 1. Air temperature

4 averages were $19.6^{\circ} \mathrm{C}$ for 2009 and $19.2^{\circ} \mathrm{C}$ for 2010 respectively; minimum and maximum

5 air temperature values were $17.6^{\circ} \mathrm{C}$ and $22.9^{\circ} \mathrm{C}$ for 2009 , and $17.2^{\circ} \mathrm{C}$ and $22.9^{\circ} \mathrm{C}$ for 2010 .

6 Vapor pressure deficit (VPD) ranged between 0.38 to $1.98 \mathrm{kPa}$ for 2009 , and 0.33 to 1.80

$7 \mathrm{kPa}$ for 2010; averages values were $1.11 \mathrm{kPa}$ and $1.05 \mathrm{kPa}$, respectively. Wind speed was

8 higher for 2010 than 2009; mean daily values were rarely above $2 \mathrm{~m} \mathrm{~s}^{-1}$ although maximum

9 gusts of $4.9 \mathrm{~m} \mathrm{~s}^{-1}$ (in 2009) and $6.1 \mathrm{~m} \mathrm{~s}^{-1}$ (in 2010) were reached; seasonal average wind

10 speed was $0.8 \mathrm{~m} \mathrm{~s}^{-1}$ for 2009 , and $1.1 \mathrm{~m} \mathrm{~s}^{-1}$ for 2010 . In accordance with these differences in

11 the meteorological conditions, there also were some differences between the

12 corresponding estimates of $\mathrm{ET}_{\mathrm{o}}$ (Figure 1). The $\mathrm{ET}_{\mathrm{o}}$ ranged between 3.6 to $7.3 \mathrm{~mm}^{-1}$ fay ${ }^{-1}$ for

132009 , and 2.6 to $7.2 \mathrm{~mm} \mathrm{day}^{-1}$ for 2010; the average $\mathrm{ET}_{\mathrm{o}}$ values were $4.8 \mathrm{~mm}$ day-1 for 2009

14 and $4.7 \mathrm{~mm} \mathrm{day}^{-1}$ for 2010. The main difference in $\mathrm{ET}_{\mathrm{o}}$ between both seasons was observed

15 during July and August when $\mathrm{ET}_{\mathrm{o}}$ rates for 2010 were much lower. This difference was

16 mainly due to the lower VPD values observed for 2010 (Figure 1). The decrease in ETo and

17 VPD observed for the summer period for both years was due to higher precipitation

18 amounts recorded during this period. Precipitation in summer is relatively high at the

19 study area, leading to slightly lower temperatures and a reduction of the dryness of the

20 air.

21 The crop coefficient curves used to estimate crop water requirements for both treatments

22 are plotted in Figure 2. The KCFtU values estimated from Equation 1 led to different curves

23 for both corn seasons due to the different values of total cumulative thermal units (TTU).

24 The value of TTU used for 2009 was $6.1 \%$ lower than that for 2010 resulting in smaller 
1 values of crop coefficients at the end of the 2009 season. In addition, the 2010 season was

2 slightly cooler than the 2009 season, particularly in the second-half of the season (Fig. 1).

3 This situation led to a $\mathrm{K}_{\text {тти }}$ curve for 2010 slightly longer than that for 2009. Seasonal

4 average $\mathrm{KC}_{\mathrm{FTU}}$ was about 7.1 \% greater for 2010 (0.91 for 2009, and 0.98 for 2010), while

5 seasonal $\mathrm{KC}_{\mathrm{FAO}}$ was 0.81 for both seasons. Figure 2 shows that the $\mathrm{KC}_{\mathrm{FTU}}$ values were

6 greater for 2009 than those for 2010 when the Kc curve was rising (from beginning of crop

7 season to maximum $\mathrm{Kc}$ ); the opposite occurred when the Kc curve was declining (from

8 maximum $\mathrm{K}_{\mathrm{c}}$ to end of crop season). The equation (1) implies that a maximum value of

$9 \quad \mathrm{~K}_{\mathrm{FTU}}=1.37$ will be reached when FTU $=0.625$. In this work this occurred 84 and 88 days

10 after sowing for 2009 and 2010, respectively. Differences between $K_{C_{F T U}}(2009$ and 2010)

11 and $\mathrm{KC}_{\mathrm{FAO}}$ occurred mainly during the initial and development stages. This difference also

12 shows the importance of using local, real-time meteorological data for scheduling

13 irrigation. Thus the $\mathrm{K}_{\mathrm{FAO}}$ values used in this study were obtained at a location (Calera

14 Aquifer) with an average air temperature $\left(18.2^{\circ} \mathrm{C}\right.$ for the period 2005 to 2008$)$ lower than

15 that in the commercial plot where this study was performed $\left(19.6^{\circ} \mathrm{C}\right.$ and $19.2^{\circ} \mathrm{C}$ in 2009

16 and 2010). This lower temperature at the Calera Aquifer led to a longer initial and

17 development stages when using the $\mathrm{K}_{\mathrm{FAO}}$ curve as compared to the $\mathrm{K}_{\mathrm{FTU}}$ curve.

18

19 Corn crop water requirements and irrigation scheduling

20 Figure 3 shows 10-day values of estimated effective precipitation. The total effective 21 precipitation during 2009 (148 mm) was about 35\% higher than that for 2010 (96 mm). A

22 great proportion of the effective precipitation occurred during the period June 21 to June 2330 for both years: $34 \%$ for 2009, and $26 \%$ for 2010. Most of the remaining seasonal 
1 effective precipitation occurred during the last third of the corn season: $45 \%$ for 2009 and

$268 \%$ for 2010.

3 The values of the net crop water requirements $\left(\mathrm{CWR}_{\mathrm{s}}, \mathrm{Eq} .4\right)$ estimated for each irrigation

4 event during each year of experimentation are presented on Figure 4. The number of

5 irrigation events was 8 for 2009 and 16 for 2010 because of the different irrigation system

6 used during those two seasons, furrow irrigation and solid-set sprinkler irrigation,

7 respectively. Subsequently, the average values of $\mathrm{CWR}_{\mathrm{s}}$ per irrigation event were higher

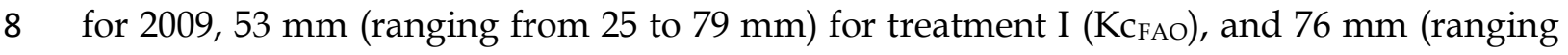

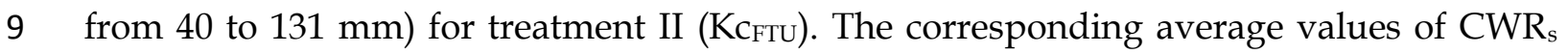

10 for 2010 were $28 \mathrm{~mm}$ (ranging from 12 to $59 \mathrm{~mm}$ ) for treatment $\mathrm{I}$, and $37 \mathrm{~mm}$ (ranging

11 from 13 to $69 \mathrm{~mm}$ ) for treatment II.

12 Figure 4 shows that the values of $\mathrm{CWR}_{\mathrm{s}}$ for both treatments were relatively similar for the

13 second half of the crop season, while $\mathrm{CWR}_{\mathrm{s}}$ for treatment II was much higher during the

14 first half of the crop season. This was the consequence of the different crop coefficient

15 curves for both treatments (Fig. 3). The Kc curve for treatment I (KCFAO) was shifted with

16 respect to the curve for treatment II $\left(\mathrm{K}_{\left.\mathrm{C}_{\mathrm{FTU}}\right)}\right)$ and the peak values for treatment I were

17 delayed with respect to those for treatment II. The $\mathrm{K}_{\mathrm{FAO}}$ curve was applied using

18 information from previous works (Mojarro et al., 2008) and it may not completely

19 correspond to the current phenological development for the particular cultivar and

20 climatic conditions of this study. Martínez-Cob (2008) used the current phenological

21 development and climatic conditions of the particular cultivar used in his study, obtaining

22 a better similarity between the $\mathrm{K}_{\mathrm{FAO}}$ and the $\mathrm{K}_{\mathrm{FTU}}$ curves and a moderately higher

23 estimated $\mathrm{CWR}_{\mathrm{s}}$ values for the FAO approach. In accordance with the abovementioned

24 results, the total irrigation gross depth (IGD, Eq. 7) applied was also higher for 2009 than 
1 for 2010: $610 \mathrm{~mm}$ (treatment I) and $762 \mathrm{~mm}$ (treatment II) for 2009, and $527 \mathrm{~mm}$ (treatment

2 I) and $701 \mathrm{~mm}$ (treatment II) for 2010 (Table 1). Thus, IGD for 2009 was about $16 \%$ higher

3 than that for 2010 for treatment I, and about $8 \%$ higher for treatment II.

4 Table 2 shows the grain corn yield, the water productivity and the economic productivity

5 for the two treatments for both seasons. The grain yield was significantly $(\mathrm{P}<0.05)$ higher

6 for treatment II than for treatment I for both years, about $37.5 \%$ for 2009 and $28.8 \%$ for

7 2010; agreeing with results obtained by previous researches (Ko and Piccinni 2009; Voires

8 et al. 2009; Payero et al. 2006) about yield increase with irrigation to the extent that crop

9 evapotranspiration is satisfied. For all cases, these grain yields exceeded the average yield

10 for the semi-arid climatic conditions of the state of Zacatecas (5.37 Mg ha-1). The higher

11 yields obtained for treatment II indicate that actual crop evapotranspiration (consumptive

12 water use) was higher for that treatment as there is a strong positive relationship between

13 grain yield and evapotranspiration (Howell, 1990). In other words, treatment I led to an

14 underestimation of actual crop water requirements (and gross irrigation needs). Thus

15 these were not adequately met and the crop suffered water stress leading to lower grain

16 yields. Treatment II was able to meet more adequately those crop water requirements and

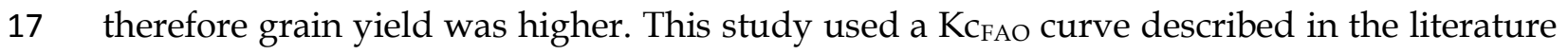

18 (Mojarro et al., 2008) and therefore may not be adequately adjusted according to the

19 particular conditions (climatic and cultivar) of the experimental seasons. Martínez-Cob

20 (2008) used current phenological development and climatic conditions when estimating

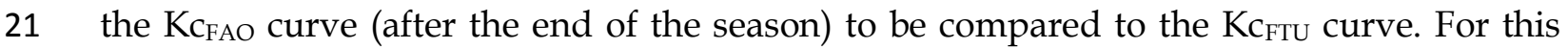

22 reason, the computed ET values with these two approaches by Martínez-Cob (2008)

23 showed a much lower difference (about $8 \%$ ) among them. This reflects the importance of

24 using crop coefficient curves that match more closely the particular conditions of each 
1 season. For irrigation scheduling, the need for a previous knowledge of phenological

2 development implicit in the FAO approach as described by Allen et al. (1998) imposes an

3 important limitation for an accurate estimation of current crop water requirements. Use of

4 variables such as the FTU, which can be easily obtained as the season progresses, can

5 improve those estimations leading to higher grain yields.

6 On the other hand, during 2009, the average water productivity for treatment I was lower,

$7 \quad 1.10 \mathrm{~kg} \mathrm{~m}^{-3}$ than that for treatment II, $1.21 \mathrm{~kg} \mathrm{~m}^{-3}$; nevertheless, in 2010, this indicator for

8 treatment I was slightly higher, $1.38 \mathrm{~kg} \mathrm{~m}^{-3}$ than that for treatment II, $1.34 \mathrm{~kg} \mathrm{~m}^{-3}$ (Table 2).

9 These differences were not significant $(\mathrm{P}>0.05)$. Kiziloglu et al. (2009) reported water 10 productivity for corn crop of $1.48 \mathrm{~kg} \mathrm{~m}^{-3}$ and $1.53 \mathrm{~kg} \mathrm{~m}^{-3}$ using irrigation doses of $352.8 \mathrm{~mm}$

11 (the water needed to satisfy $100 \%$ of actual crop evapotranspiration), and $282.2 \mathrm{~mm}$

12 (irrigation water applied just to satisfy the $80 \%$ of full irrigation) respectively. In addition, 13 the economic productivity was also significantly higher $(\mathrm{P}<0.05)$ for treatment II, $2162 \$$

14 ha $^{-1}$ (during 2009 and 2010), than that for treatment I, 1575 \$ ha-1 (during 2009) and 1679 \$ 15 ha $^{-1}$ (during 2010). Table 2 also shows that the differences between years for treatment I, in 16 terms of water and economic productivity, were about $25 \%$ and $7 \%$ respectively while for 17 treatment II water productivity increased by about $11 \%$ from 2009 to 2010; nevertheless 18 economic productivity remains equal. Comparing these same indicators but between 19 treatments results that water productivity was about $10 \%$ higher for treatment II during 202009 and 3\% lower during 2010 than that of treatment I while economic productivity in 21 both years was higher for treatment II than that of treatment I (37 \% and $29 \%$ 22 respectively). Therefore, the use of the FTU to estimate crop water requirements have led 23 to higher corn yields and lower year-to-year variability in terms of water and economic 
1 productivity. Of course, two years of study is not too much and a longer and more

2 detailed analysis should be performed.

3

4

5

6

7

8

9

10

11

12

13

14

15

16

17

18

19

20 


\section{Conclusions}

2 Two irrigation scheduling treatments were evaluated during two corn crop seasons, 2009

3 and 2010: treatment I, using Kc values computed using the FAO methodology; and

4 treatment II, using Kc values computed using an equation developed by Martínez-Cob

5 (2008) to estimate them from fraction of thermal units. Corn crop water requirements and

6 irrigation doses were estimated for the two treatments as well as water use productivity

7 and corn crop production. Total net crop water requirements estimated for each irrigation

8 event were $427 \mathrm{~mm}$ (2009), and $448 \mathrm{~mm}$ (2010) for treatment I; and $533 \mathrm{~mm}$ (2009), and 596

$9 \mathrm{~mm}$ (2010) for treatment II. Nevertheless, the use of fraction of thermal units to estimate

10 corn crop coefficients provided better results against FAO methodology in terms of corn

11 production. Thus, grain yield was higher for treatment II than for treatment I for both

12 years, about $37.5 \%$ for 2009 and $28.8 \%$ for 2010. In addition, the economic productivity

13 was higher for treatment II, $2162 \$$ ha $^{-1}$ (during 2009 and 2010), than that for treatment I,

$141575 \$$ ha-1 $^{-1}$ (during 2009) and $1679 \$$ ha $^{-1}$ (during 2010). On the other hand, water

15 productivity was $10 \%$ lower for treatment I than for treatment II for 2009, but in 2010 was

$163 \%$ higher for treatment I than for treatment II.

17 These results confirm that the use of fraction of thermal units to estimate corn crop

18 coefficient has improved the yield, and the water management of this crop under the

19 conditions of this study. This improvement seemed to be somewhat higher when using

20 furrow irrigation system as compared to sprinkler irrigation. Because of the limitations of

21 the study (only two years and one experimental plot), further evaluations under other

22 conditions should be performed. 
1

2

3

4

5

\section{$\underline{\text { References }}$}

Allen, R. G., Pereira, L. S., Raes, D., and Smith, M. (1998). “Crop evapotranspiration: guidelines for computing crop water requirements". FAO Irrigation and Drainage Paper 56. FAO, Rome.

Amos, B., Stone, L. R., and Bark, L. D. (1989). "Fraction of thermal units as the base for evapotranspiration crop coefficient curve for corn". Agronomy Journal, 81:713-717.

Bezerra, B. G., da Silva, B. B., Bezerra, J. R. C., and Sofiatti, V. (2012). “Evapotranspiration and crop coefficient for sprinkler-irrigated cotton crop in Apodi Plateau semiarid lands of Brazil". Agricultural Water Management 107:86-93.

Christiansen, J. E. (1942). “Irrigation by sprinkling”. Agric. Exp. Stn. Bull. 670. Univ. of California, Berkeley.

Dehghanisanij, H., Nakhjavani, M. M., Tahiri, A. Z., and Anyoji, H. (2009). “Assessment of wheat and maize water productivities and production function for cropping system decisions in arid and semiarid regions". Irrigation and Drainage 58:105-115.

Dioudis, P., Filintas, A. T., Papadopoulos, A. H. (2009). “Corn yield response to irrigation interval and the resultant savings in water and other overheads". Irrigation and Drainage 58:96-104.

Grattan, S. R., Bowers, W., Dong, A., Snyder, R. L., Carroll, J. J., and George, W. (1998). "New crop coefficients estimate water use of vegetables, row crops". California Agriculture, 52(1):16-21.

Howell, T. A. (2003). "Irrigation Efficiency”. Encyclopedia of Water Science, Marcel Dekker Inc., New York, USA, 467-472.

Howell, T. A. (1990). "Relationships between crop production and transpiration, evapotranspiration and irrigation". Irrigation of agricultural crops, Stewart B. A., 
Nielsen D. R., eds., Agronomy Series No 30. 391-434. ASA-CSSA-SSSA, Madison, WI, USA.

Kang, S. Z., Gu, B. J., Du, T. S., and Zhang, J. H. (2003). “Crop coefficient and ratio of transpiration to evapotranspiration of winter wheat and maize in a semi-humid region". Agricultural Water Management, 59(3):239-254.

Kar, G., Kumar, A., and Martha, M. (2007). “Water use efficiency and crop coefficients of dry season oilseed crops". Agricultural Water Management 87:73-82.

Kiziloglu, F. M., Sahin, U., Kuslu, Y., and Tunc, T. (2009). “Determining water-yield relationship, water use efficiency, crop and pan coefficients for silage maize in a semiarid region". Irrigation Science, 27:129-137

Ko, J., and Piccinn, G. (2009). “Corn yield responses under crop evapotranspiration-based irrigation management". Agricultural Water Management 96:799-808.

López-Urrea, R., Montoro, A., López-Fuster, P., and Fereres, E. (2009). “Evapotranspiration and responses to irrigation of broccoli". Agricultural Water Management 96:11551161.

Martínez-Cob, A. (2008). "Use of thermal units to estimate corn crop coefficients under semiarid climatic conditions". Irrigation Science, 26:335-345.

Merriam, J. L. and Keller, J. (1978). “Farm irrigation system evaluation: a guide for management". Utah State University, Logan, Utah.

Mojarro, D. F., Bautista-Capetillo C., Ortiz, V. J. and Vázquez, F. E. (2012) “Comparing water performance by two different surface irrigation methods". Irrigation-Water Management, Pollution and Alternative Strategies, García-Garizabal, I. ed., Rijeka, Croatia. 
Mojarro, D. F., Gonzalez, T. J., Gutiérrez, N. J. A., Toledo, B. A., and Araiza, E. J. A. (2008). "Software PIREZ (Proyecto Integral de Riego para el Estado de Zacatecas)" Universidad Autónoma de Zacatecas, Mexico.

Nielsen, D. C., and Hinkle, S. E. (1996). “Field evaluation of basal crop coefficients for corn based on growing degree days, growth stage, or time". Transactions of the ASAE, 39(1):97-103.

Ojeda-Bustamante, W., Sifuentes-Ibarra, E., Slack. D. S., and Carrillo, M. (2004). "Generalization of irrigation scheduling parameters using the growing degree days concept: application to a potato crop". Irrigation and Drainage, 53: 251-261.

Ojeda-Bustamante, W., Sifuentes-Ibarra, E., and Unland-Weiss, H. (2006). "Integral programming for corn irrigation in Northern Sinaloa, Mexico". Agrociencia, 40:13-25.

Payero, J. O., Melvin, S. R., Irmak, S., and Tarkalson, D. (2006). “Yield response of corn to deficit irrigation in a semiarid climate". Agricultural Water Management, 84(1-2):101112.

Ritchie, J. T., and NeSmith, D. S., (1991). “Temperature and crop development”. Hanks, J., and Ritchie, J. T., eds. Modeling plant and soil systems. Series Agronomy No 31. American Society of Agronomy, Crop Science Society of America, Soil Science Society of America, Madison, pp 5-29.

Ruiz-Corral, J. A., Flores-López, H. E., Ramírez-Díaz, J. L., and González-Eguiarte, D. R. (2002). “Cardinal temperatures and length of maturation cycle of maize hybrid H-311 under rainfed conditions". Agrociencia, 36:569-577.

Sammis, T. W., Mapel, C. L., Lugg, D. G., Lansford, R. R., and McGuckin, J. T. (1985). "Evapotranspiration crop coefficients predicted using growing-degree-days". Transactions of the ASAE, 28(3):773-780. 
1 Sepaskhah, A. R., and Andam, M. (2001). “Crop coefficient of sesame in a semiarid region 2 of IR Iran". Agricultural Water Management, 49:51-63.

3 Steele, D. D., Sajid, A. H., and Prunty, L. D. (1996). “New corn evapotranspiration crop 4 curves for southeastern North Dakota". Transactions of the ASAE, 39(3):931-936.

5 Tyagi, N. K., Sharma, D. K., and Luthra, S. K. (2003). “Determination of evapotranspiration 6 for maize and berseem clover". Irrigation Science, 21:173-181.

7 Vories, E. D., Tacker, P. L., Lancaster, S. W., and Glover, R. E. (2009). “Subsurface drip 8 irrigation of corn in the United States Mid-South". Agricultural Water Management, $9 \quad 96: 912-916$.

10 Yan, W., and Hunt, L. A. (1999). “An equation for modelling the temperature response of 11 plants using only the cardinal temperatures". Annals of Botany, 84:607-614.

12 13 14 15 16 17 18 19 20 21 22 


\section{$1 \quad$ List of Tables}

2 Table 1. Crop water requirements (CWR), irrigation gross depth applied (IGD), and effective 3 precipitation (PEF) values for 2009 and 2010 corn seasons. Treatment I, scheduling irrigation $4 \quad$ using a crop coefficient computed following Allen et al. (1998); treatment II, scheduling 5 irrigation using a crop coefficient computed following Martínez-Cob (2008).

6

7 Table 2. Performance indicators for 2009 and 2010 corn seasons. Treatment I, scheduling 8 irrigation using a crop coefficient computed following Allen et al. (1998); treatment II, 9 scheduling irrigation using a crop coefficient computed following Martínez-Cob (2008).

10

11

12

13

14

15

16

17

18

19

20

21

22

23

24 


\section{List of Figures}

2 Figure 1. 10-day averages of the daily mean meteorological conditions recorded at the nearby 3 station during the 2009 and 2010 corn seasons. Daily vapor pressure deficit (VPD) and $4 \quad$ reference evapotranspiration computed following Allen et al. (1998).

5

6 Figure 2. Crop coefficient curves used to estimate crop water requirements for: treatment I, using a 7 crop coefficient (Kc) curve computed following Allen et al. (1998) (FAO); and treatment II, using a Kc curve computed following Martínez-Cob (2008) (FTU).

9

10 Figure 3. Cumulative effective precipitation for 10-day periods occurred during the 2009 and 2010

11 corn seasons.

12

13 Figure 4. Net corn crop water requirements for: treatment I, crop coefficient computed following 14 Allen et al. (1998) (FAO); and treatment II, crop coefficient computed following Martínez-Cob (2008) (FTU), during two seasons: 2009 and 2010.

16 
1 Table 1. Crop water requirements (CWR), irrigation gross depth applied (IGD), and effective precipitation (PEF) values for 2009 and 2010 corn

2 seasons. Treatment I, scheduling irrigation using a crop coefficient computed following Allen et al. (1998); treatment II, scheduling irrigation

3 using a crop coefficient computed following Martinez-Cob (2008)

4

5

\begin{tabular}{cccccc}
\hline Year & \multicolumn{2}{c}{$\begin{array}{c}\text { CWRs } \\
(\mathrm{mm})\end{array}$} & \multicolumn{2}{c}{$\begin{array}{c}\text { IGD } \\
(\mathrm{mm})\end{array}$} & $\begin{array}{c}\text { PEFs } \\
(\mathrm{mm})\end{array}$ \\
\hline & $\mathrm{I}$ & $\mathrm{II}$ & $\mathrm{I}$ & $\mathrm{II}$ & \\
2009 & 427.1 & 533.3 & 610.1 & 761.8 & 148.1 \\
2010 & 448.1 & 596.0 & 527.1 & 701.2 & 96.0 \\
\hline
\end{tabular}


1 Table 2. Performance indicators for 2009 and 2010 corn seasons. Treatment I, scheduling irrigation using a crop coefficient computed following

2 Allen et al. (1998); treatment II, scheduling irrigation using a crop coefficient computed following Martinez-Cob (2008)

3

\begin{tabular}{ccccccc}
\hline Year & \multicolumn{2}{c}{$\begin{array}{c}\text { Grain yield }{ }^{\ddagger} \\
\left(\mathrm{Mg} \mathrm{ha}^{-1}\right)\end{array}$} & \multicolumn{2}{c}{$\begin{array}{c}\text { Water productivity } \\
\left(\mathrm{Kg} \mathrm{m}^{-3}\right)\end{array}$} & \multicolumn{2}{c}{$\begin{array}{c}\text { Economic productivity } \\
\left(\$ \text { ha }^{-1}\right)\end{array}$} \\
\hline & I & II & I & II & I & II \\
2009 & $6.70^{\mathrm{a}}$ & $9.20^{\mathrm{b}}$ & $1.10^{\mathrm{a}}$ & $1.21^{\mathrm{a}}$ & $1575^{\mathrm{a}}$ & $2162^{\mathrm{b}}$ \\
& & & & & & \\
2010 & $7.30^{\mathrm{a}}$ & $9.40^{\mathrm{b}}$ & $1.38^{\mathrm{a}}$ & $1.34^{\mathrm{a}}$ & $1679^{\mathrm{a}}$ & $2162^{\mathrm{b}}$ \\
\hline
\end{tabular}

4

₹ Different letters indicate that the treatments were significantly different and same letters indicate that the treatments were not

$6 \quad$ significantly different $(\mathrm{P}<0.05)$. 
Figure 1. 10-day averages of the daily mean meteorological conditions recorded at the nearby station during the 2009 and 2010 com seasons. Daily vapor pressure deficit (VPD) and reference evapotranspiration computed following Allen et al. (1998).
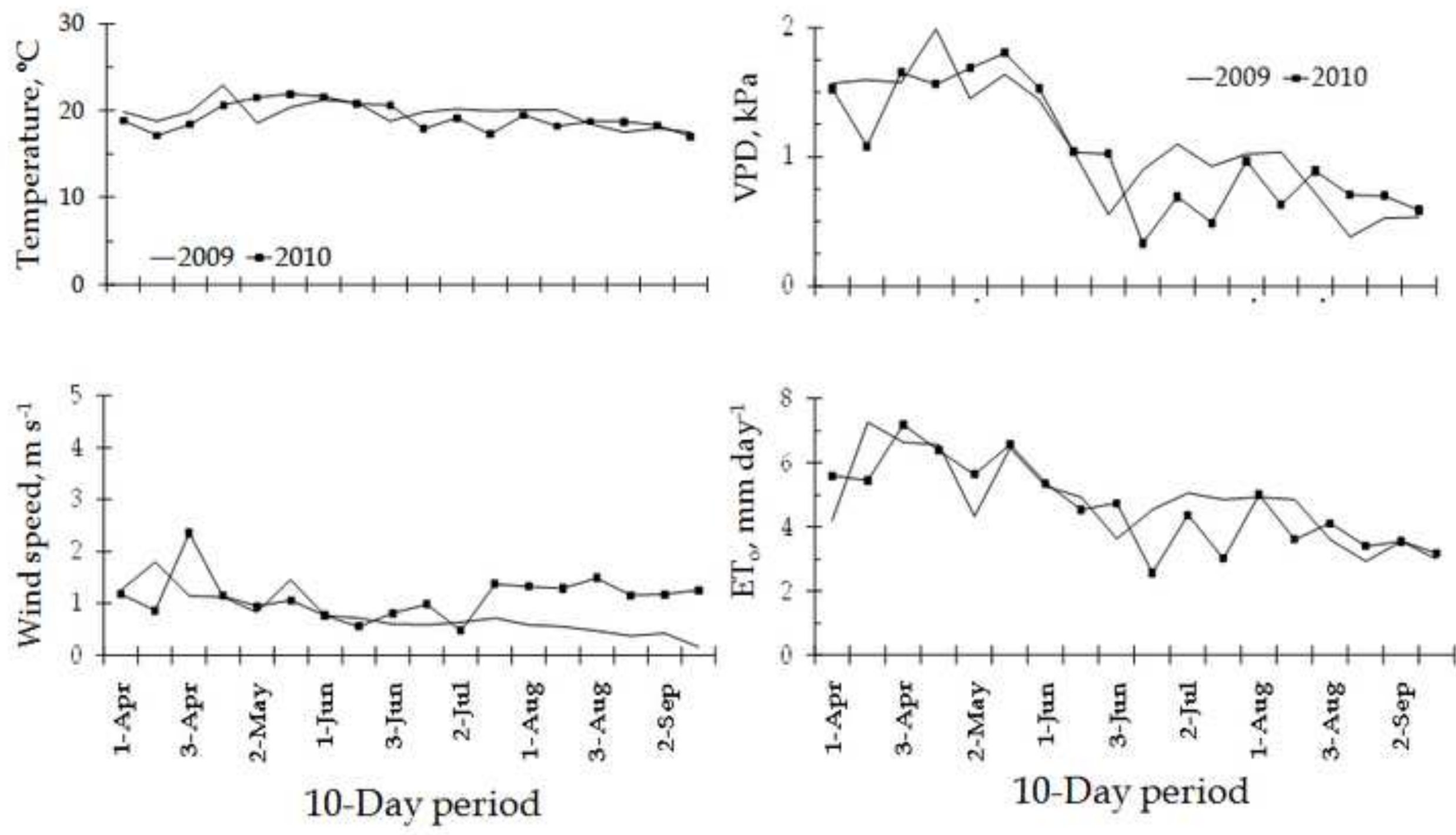
Figure 2. Crop coefficient curves used to estimate crop water requirements for: treatment $I$, using a crop coefficient (Kc) curve computed following Allen et al. (1998) (FAO); and treatment II, using a Kc curve computed following Martinez-Cob (2008) (FTU)

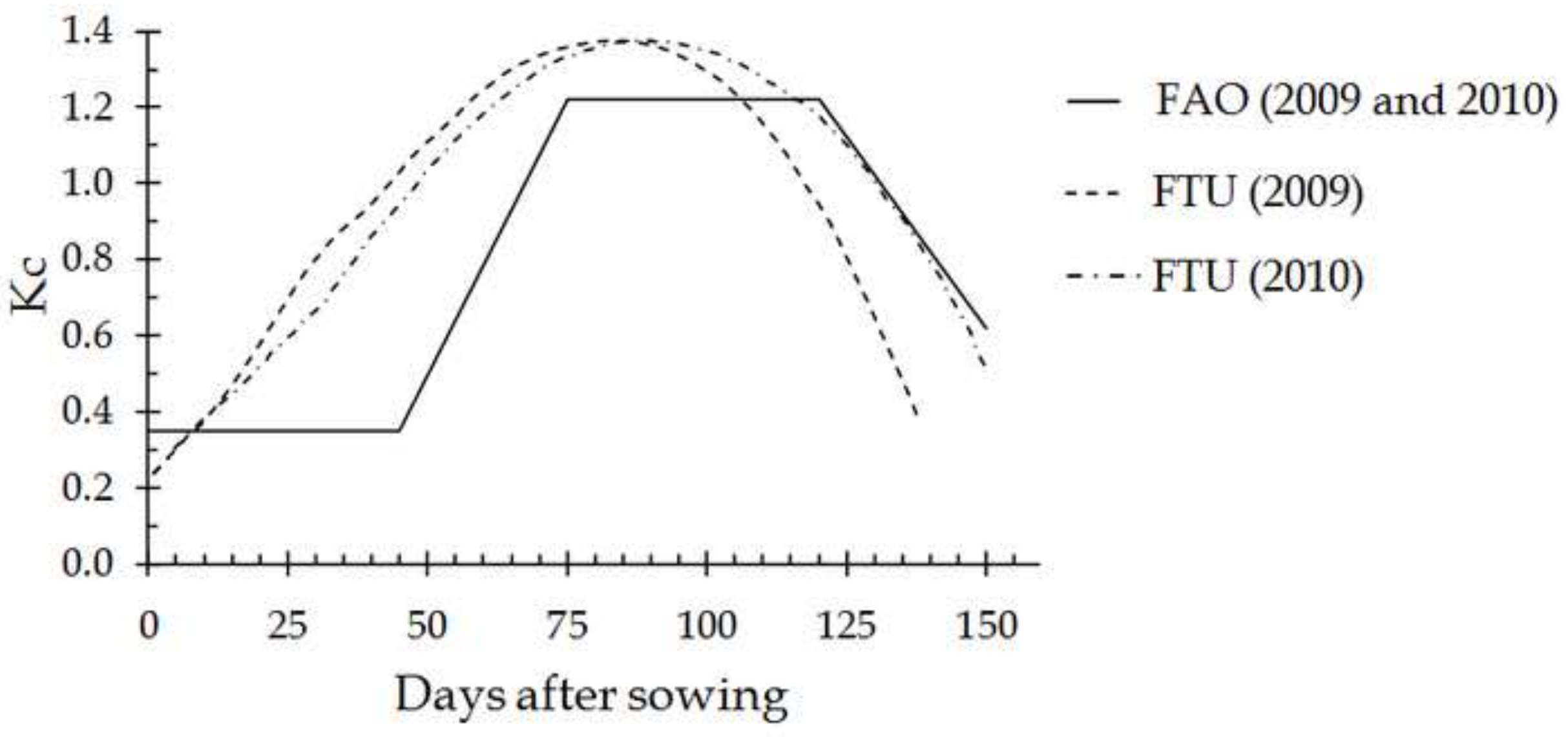


Figure 3. Cumulative effective precipitation for 10-day periods occurred during the 2009 and 2010 corn seasons

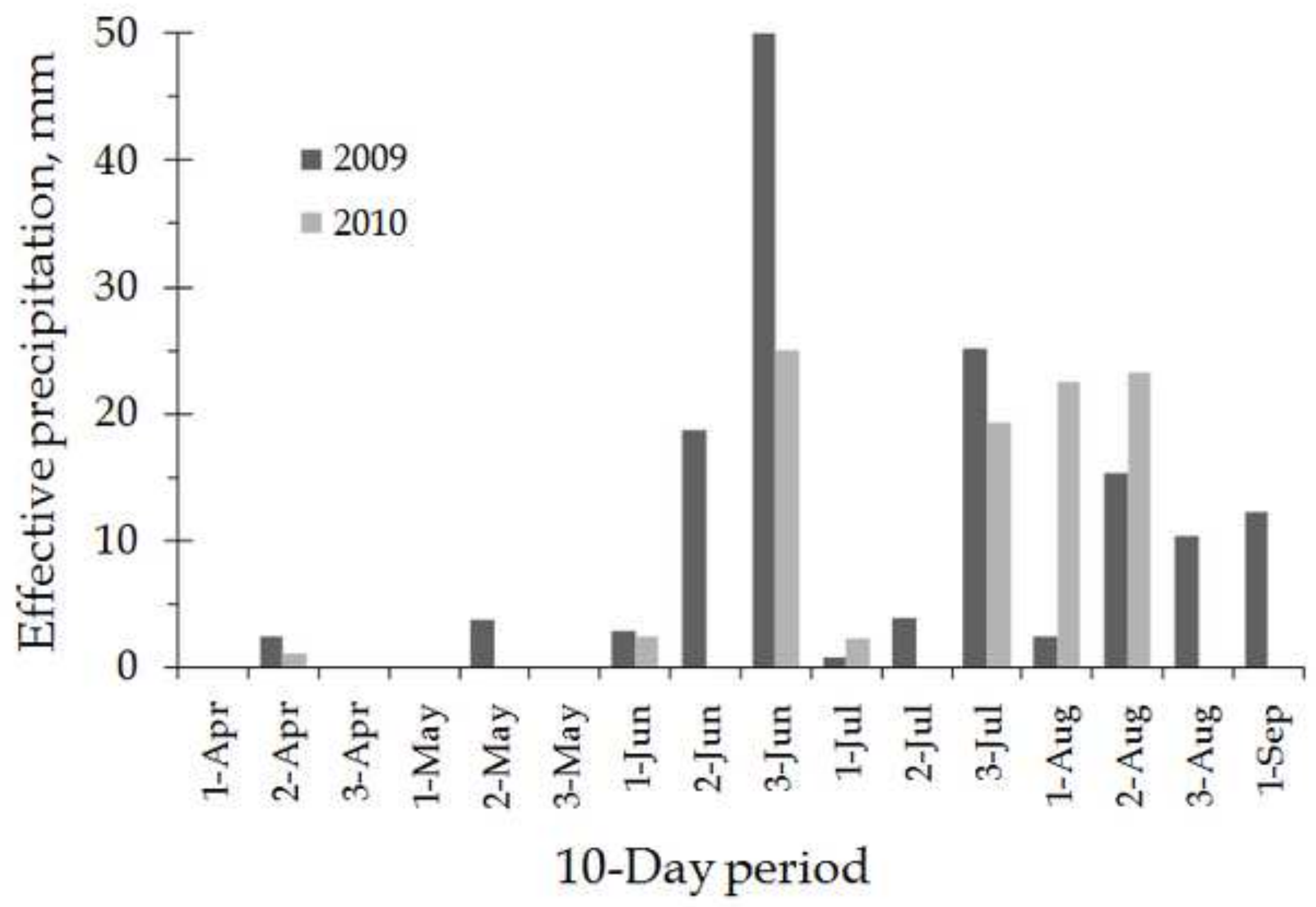


Figure 4. Net com crop water requirements for: treatment I, crop coefficient computed following Allen et al. (1998) (FAO); and treatment II, crop coefficient computed following Martinez-Cob (2008) (FTU), during two seasons: 2009 and 2010.

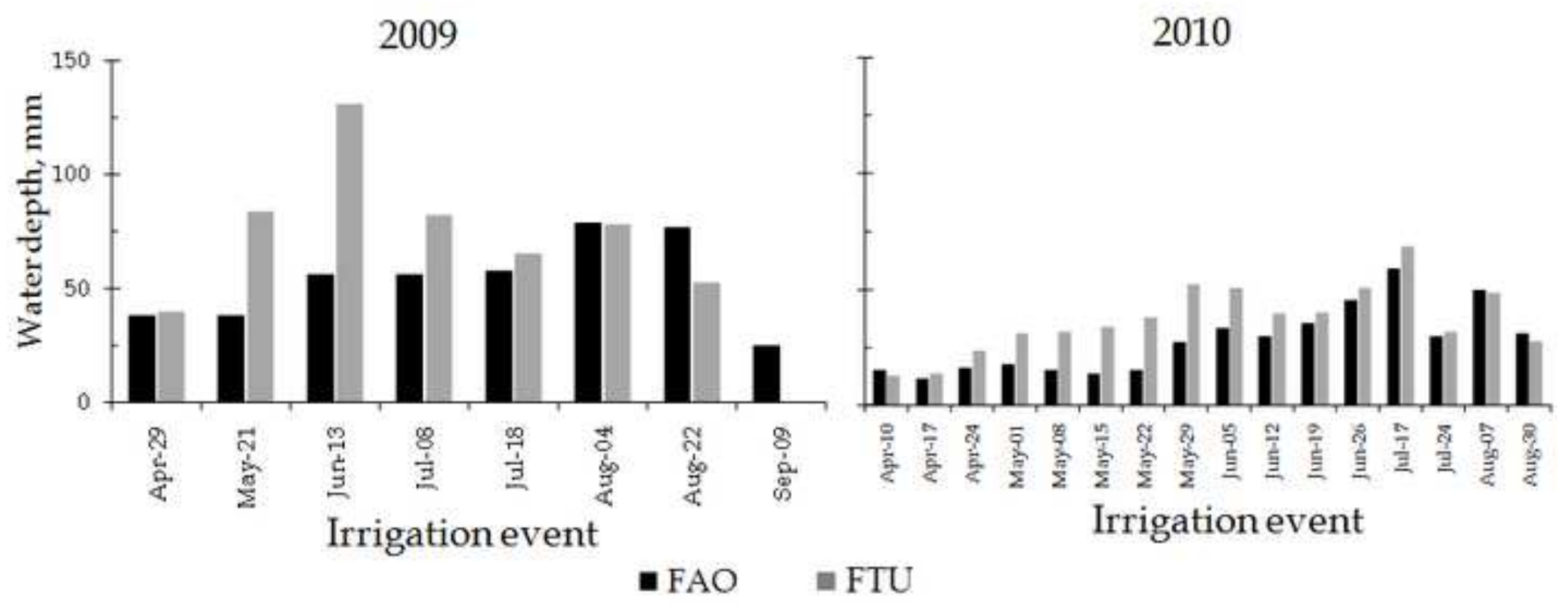

